\title{
EFFECT OF THE INSTRUCTIONAL ENVIRONMENT IN GIRLS' HIGHER SECONDARY SCHOOLS ON THE PERFORMANCE OF SUBJECT SPECIALISTS
}

\author{
Samina Naz ${ }^{1 *}$, Malik Amir Atta ${ }^{2}$, Abdul Ahad Roshan Saeed ${ }^{3}$, Shagufta $\mathrm{Naz}^{4}$
}

${ }^{1 *}$ Ph.D., Scholar, Institute of Education and Research, Gomal University, D. I. Khan, Pakistan; ${ }^{2}$ Assistant Professor, Institute of Education and Research, Gomal University, D. I. Khan, Pakistan; ${ }^{3}$ Lecture, Education, Mir Chakar Khan Rind University, Sibi, Balochistan, Pakistan, ${ }^{4}$ Ph.D., Scholar, Institute of Education and Research, Gomal University, D. I. Khan, Pakistan. Email: ${ }^{1 *}$ sam.gandapur@gmail.com, ${ }^{2}$ malikamiratta @ gmail.com, ${ }^{3}$ iamroshansaeed@ gmail.com, Article History: Received on $30^{\text {th }}$ May 2021, Revised on $7^{\text {th }}$ June 2021, Published on $9^{\text {th }}$ June 2021

\begin{abstract}
Purpose of the study: This study was intended to reveal the effect of the instructional environment on the performance of the subject specialists. The purpose of the was to find out correlation exists between instructional environment and performance of the SS in terms of exam results of students in HSSC Part II and to find out correlation exists between the performance of SS within the classroom and the availability of a conducive instructional environment in schools.
\end{abstract}

Methodology: Quantitative method with descriptive research was used in this study. Checklist and student's exam results were used to collect the data and analyses were done through SPSS.

Main Findings: There found a significant negative correlation between instructional environment and performance of the SS in terms of exam results of students in HSSC Part II and there found a significant negative correlation between the performance of SS within the classroom and the availability of a conducive instructional environment in schools.

Applications of this study: This study is applicable in the given context of Southern districts of Khyber Pakhtunkhwa as well as the results can be utilized and checked in another context within the province and in the country. This study will surely contribute to bringing the attention of policymakers and government officials to put their efforts into improving the current situation related to the instructional environment and performance of the subject specialists.

Novelty/Originality of this study: The novelty of this study lies in the results that contradict usual and normal results that show that the instructional environment has a positive association with the performance of the teachers. This study brings into light the opposite side of the worldwide results. This will open grounds for future researchers to work in this area in different contexts to explore that whether a negative correlation exists in other contexts and if so, what factors are contributing to developing such a negative relationship.

Keywords: Instructional Environment, Performance, Subject Specialists, Girls Secondary Schools.

\section{INTRODUCTION}

Successful organizations are made by the workers through their performance. The environment is very important in determining the performance of the workers in any field and profession (Lious et al., 2021) and for teachers, it is the classroom instructional environment that they create that also impacts their performance as well as the performance of their students. Education, the process of imparting knowledge, beliefs, religion, norms, and values to the next generation, is a complicated process that requires systematic coordination and cooperation of all the stakeholders; society, teachers, administration, and the students. It targets to develop not only the cognitive part of the child's brain but also ensures a comprehensive learning experience for the children in terms of sociological, moral, emotional, religious, and physical development. Teachers are key factors and hence their performance matters a lot. A teacher's competence is comprised of pre-instruction, presentation, creating an instructional/learning atmosphere, students' learning, and professional behaviour/attitude (Medley, 1977 as cited in Ye, 2017). According to Iqbal (1986), the Educational process works in a very clandestine way, bringing about transformation gradually without showing any drastic and overnight changes. The stakeholders have to play their respective parts desirably so that a conducive instructional environment is provided to the students ensuring achievement of the targets. Arif (2003) limits the instructional environment to the physical and environmental facilities available to the teachers and the taught. The instructional environment comprises 3 main features; the teaching and instructional procedures going on within the classroom, nature of interpersonal relationships between the stakeholders; teachers, students, and the administration and lastly the unique personal features of the classroom that ensure optimal results after the successful completion of the teaching-learning process (Korir \& Kipkebut, 2016; Harrison \& Jones, 2012). The learning/instructional environment is necessary for the well-being of the students and has a direct impact on the achievement of the students (Baroody \& Diamond, 2016; Han et al., 2017). This instructional environment also influences the performance of the teachers as well. A good environment leads to better performance and vice-versa.

When looked at from the teachers' point of view, a favorable work environment in the school is only possible if there exists a collective sense of responsibility within all the stakeholders; the administration, parents, and community, aiming 
to improve learning among the students (Buckley, 2005). It is the responsibility of the school administration and the education authorities to ensure the creation of such an environment that results in creating helpful situations leading to a safe and satisfactory workplace for teachers (Marry, 2010). An instructional environment that is conducive to learning procedures, needs to look into the specific requirements and needs of the students (Lynch, 2012). Teacher performance, on other hand, cannot be evaluated from a single standpoint. According to Shishigu (2015), evaluation and measurement of the teacher are performing, is a complicated phenomenon and there are no single criteria upon which a teacher's performance can be labeled as better or worse. Relying on a single technique can sometimes give biased results (Cascio, 2006). According to Dornyei (2001), Systematic observations by a trained observer, evaluations done by the students, knowledge-based tests for the teachers, participation in training and workshops as well as the performance score of the students, all or some should be used before passing any judgement about any teacher's performance (Ofoegbu, 2004$)$.

The main purpose of the present research is to identify the situation of the instructional environment within girls' higher secondary schools of the southern districts of KP. The researcher also targets the performance of subject specialists within the girl's higher secondary in these schools. It also aims to find out some association or otherwise between the availability of instructional environment and the performance of the subject specialists. It aims to shed light upon exploring the conditions related to the instructional environment within the girls' higher secondary schools in the southern districts of KP. This research study is unique because the researcher has judged the performance of Subject Specialists of the higher secondary schools from two perspectives; in term of the academic result of the students in HSSC Part II, and through an observational checklist that judges the performance of the subject specialists in terms of; lesson preparations, use of helping materials during the teaching process, discipline management and use of latest pedagogies during classroom activities.

\section{Objectives of Study}

1. To find out correlation exists between instructional environment and performance of the SS in terms of exam results of students in HSSC Part II

2. To find out correlation exists between the performance of SS within the classroom and the availability of a conducive instructional environment in schools.

\section{Research Hypothesis}

$\mathbf{H}_{\mathbf{0 1}}$ : There is a significant correlation exists between instructional environment and performance of the SS in terms of exam results of students in HSSC Part II

$\mathbf{H}_{\mathbf{0 2}}$ : There is a significant correlation exists between the performance of SS within the classroom and the availability of a conducive instructional environment in schools.

\section{LITERATURE REVIEW}

Changing time causes educational institutes to become highly dynamic (Ahmad et al., 2018). This changing time demands teachers to be more flexible and for creating an instructional environment in order to facilitate themselves as well as their students. Teacher's performance is one of the important areas in the field of academia (Mwangi \& Njuguna, 2019) because the teachers' performance has a special role in the field of education (Madrid et al., 2019). Teacher's low performance leads to huge loss in shape of student's academic career which generally shows the long-lasting effect on the education industry. Park, Lim, and Ju (2016) mentioned that professional improvement and professional learning needs to be done on a regular basis. The creation of a sound instructional setup is linked with their better performance. Therefore, teacher's performance has central importance in the education industry which needs to be considered by scholars as well as practitioners. A professional teacher is required to have professional qualifications and academic competencies, having good communication skills with students, ownership of creative and productive souls, have a work ethic and a great commitment to the profession, and always strives to develop themselves continuously (Hartinah et al., 2020). Teachers' instructional decisions, such as lesson goals, how students are grouped, or how students are recognized and evaluated, can affect their students' level of motivation related to physical activity (Mureithi \& Mwangi, 2019). A physical educator's primary responsibility is to create a classroom environment that enhances motivation and encourages students to become fit and to learn motor skills. If the long-term goal in physical education is to help students become physically active throughout life, then one way to achieve this goal is to create instructional environments that foster positive attitudes and behaviours' regarding healthy lifestyle choices (Haseeb \& Sattar, 2018).

If the teacher does not have good competence, students will also have bad competencies. Improving the quality of education must start from an end to the teachers (Jirangkul, 2017). Without adequate competency, it can be ascertained that the teachers will not be able to perform their role as an educator optimally indicated by the ownership of educator certification. The emergence of various problems for teachers can be caused by the lack of optimal management of teachers including, in this case, performance management (Jones et al., 2012). The teacher development program has not comprehensively taken into account the factors that influence their performance (Ikhwandra, 2016). Teacher's performance can be stated optimally besides being driven by strong internal factors (Lixia, 2017), namely; individuals (commitment, motivation, and ability). It is also supported by adequate external (situational) factors like adequate rewards (Thanomton et al., 2018), supportive leadership, and a conducive school working culture (Ruth, 2017). The 
instructional environment is needed to be created by teachers themselves in order to improve their own performance first and this will ultimately increase the performance of the students as well. The classroom layout, ambience, and other necessary facilities such as internet usage can be related and hence define the acceptability of the students and enhancement of their satisfaction (Haseeb and Sattar, 2018; Madrid et al., 2019). Different elements are combined to influence the success of any education system including social, economic, psychological, ICT technology (Basri et al., 2018) which is important for teachers for creating a better learning environment to fulfill the needs of the present time and environmental factors (Anticevic et al., 2018). Thus this study was intended to relate the influence of the instructional environment on the performance of the subject specialists.

\section{METHODOLOGY}

\section{Population of Study}

This research study was set in the backdrop of the southern districts of KP namely Dera Ismail Khan, Bannu, Karak, Kohat, Lakki-marwart, and Tank. There being a total of 42 girls in Higher Secondary schools in the southern districts, each higher secondary school was taken as a cluster that included all the students admitted in HSSC Part II and the SS working in the school. The population of the research study comprised all the students enrolled in HSSC Part II from 42 GGHSS of southern districts, which were 21947 whereas all the female subject specialists working in the 42 GGHSS of southern districts of KP numbered 358.

\section{Sample and Sampling Techniques}

The researcher used cluster sampling for the purpose of data collection. Each one of the girls' higher secondary schools was considered to be a cluster out of which the SS and students were considered to be the data-producing sample. In order to ensure maximum representation of the stakeholders, the researcher took a sample of 12 GGHSS out of 42 . All the 430 students of intermediate Part II and all the 188 subject specialists of the sampled out of 12 GGHSS clusters were taken as data-producing sample for the present research study.

\section{Research Instrument}

The instructional environment within the GGHS Schools was checked through a self-developed, duly reliable, and properly validated, observational checklist. The checklist contained items related to school structure, availability of instructional materials within and outside the classroom, opportunities for professional development for teachers, a learning-friendly environment within the school, stress on the overall development of the students within the classroom enhances teacher and student performance. On the other hand, the performance of SS was judged through two perspectives;

- A self-developed, the checklist was used in this study. The content validity was done with help of the supervisor and reliability was done by doing a pilot study first. The data was used to check Cronbach alpha value through SPSS. The value extracted was 0.71 which greater than the accepted value and thus the checklist was considered reliable. It contained items related to lesson preparations, use of the latest teaching pedagogies, the democratic environment within the classroom, use of AV aids, and management of discipline within the classroom.

- Students' academic performance in BISE Exam HSSC Part II, for the past 3 years (2015-16, 2016-17, 2017-18), obtained from the Result Gazettes provided by the BISE working within the respective districts.

\section{Statistical Analysis}

Averages and percentages were used for the descriptive analysis and in the case of inferential analysis the researcher used correlation to judge any relationship that may have existed between the variables. Descriptive analysis of the instructional environment done through checklist was looked through various angles; school structure like electricity, drinking water, adequate classrooms, availability of Instructional material within the classroom, professional development opportunities being provided to teachers, the availability of learning-friendly environment within the classroom, stress upon the comprehensive development of the child.

\section{RESULTS/FINDINGS}

Table 1: Showing scores of observational checklists about the availability of instructional environment in the schools

\begin{tabular}{lllllll}
\hline & \multicolumn{6}{l}{ Test variables in terms of instructional environment } \\
\cline { 2 - 6 } & SS (5) & IMA (5) & PD (5) & LFE (5) & CDS (5) & Total (25) \\
\hline GGHSS No 2 & 3 & 2 & 3 & 2 & 3 & 13 \\
\hline GGHSS No 9 & 4 & 3 & 3 & 2 & 2 & 14 \\
\hline GGHSS Bilot Shareef & 2 & 3 & 3 & 3 & 1 & 12 \\
\hline GGHSS Jungle Khel Kohat & 4 & 3 & 3 & 2 & 1 & 13 \\
\hline GGHSS Lachi Kohat & 2 & 2 & 3 & 2 & 1 & 10 \\
\hline GGHSS Gumbat Kohat & 3 & 2 & 3 & 2 & 1 & 11 \\
\hline
\end{tabular}




\begin{tabular}{lllllll}
\hline GGHSS Karak No1 & 3 & 2 & 3 & 2 & 1 & 11 \\
\hline GGHSS Chokara Karak & 2 & 2 & 3 & 2 & 1 & 10 \\
\hline GGHSS SK Bala & 3 & 2 & 3 & 2 & 1 & 11 \\
\hline GGHSS Kaki, Bannu & 3 & 2 & 3 & 2 & 1 & 11 \\
\hline GGHSS Titter Khel Lakki. & 3 & 2 & 3 & 2 & 1 & 11 \\
\hline GGHSS MULAZI Tank & 3 & 2 & 3 & 1 & 1 & 10 \\
\hline Average score & 2.91 & 2.25 & 3 & 2 & 1.33 & \\
\hline
\end{tabular}

SS: School Structure, Instructional Material Availability: IMA, Professional Development: PD, LFE: Learner Friendly Environment: CDS: Comprehensive Development of Students

It is quite interesting to note the researcher found the quite encouraging situation concerning the availability of school structure in the GGHS Schools. Out of a total score of 5 points, the average score achieved by the GGHSS Schools was 2.91(58\%). Availability of instructional materials like science and computer labs, internet facility, library, charts, models, reference books for SS got a score of 2.25out of 5 (45\%). Professional development opportunities for the SS got 3 out of 5 making it $(60 \%)$. It was quite depressing to note that a learner-friendly environment within the school got only 2 out of 5 making it a $40 \%$ score. Stress upon comprehensive development of the child got 1.33 out of 5 points making it a $27 \%$ score.

The researcher involved all the subject specialists (SS) working in the sampled out 12 GGHS Schools who were teaching HSSC Part II students. The observations were recorded in a checklist and later elaborated and described in detail. Based on the observational checklist, each of the SS was separately observed and assigned scores on the basis of the observation. The researcher then calculated the mean scores of all the SS of one school. The researcher assigned 5 marks to each variable.

Table 2: Showing scores of observational checklists related to the performance of the SS within the classroom

\begin{tabular}{lllllll}
\hline & \multicolumn{7}{l}{ Test variables in terms of Teacher Performance in Classroom } & Total (25) \\
\cline { 2 - 6 } & LP & UAV & DM & DCR & TT & 17 \\
\hline GGHSS No 2 & 3 & 3 & 4 & 4 & 3 & 19 \\
\hline GGHSS No 9 & 4 & 4 & 4 & 3 & 4 & 18 \\
\hline GGHSS Bilot Shareef & 4 & 3 & 4 & 3 & 4 & 15 \\
\hline GGHSS Jungle Khel Kohat & 3 & 4 & 3 & 3 & 3 & 13 \\
\hline GGHSS Lachi Kohat & 2 & 3 & 2 & 3 & 3 & 16 \\
\hline GGHSS Gumbat Kohat & 3 & 3 & 4 & 3 & 3 & 17 \\
\hline GGHSS Karak No1 & 2 & 3 & 4 & 3 & 4 & 15 \\
\hline GGHSS Chokara Karak & 4 & 3 & 4 & 3 & 3 & 14 \\
\hline GGHSS SK Bala & 3 & 2 & 3 & 4 & 3 & 17 \\
\hline GGHSS kaki, Bannu & 3 & 4 & 2 & 1 & 4 & 15 \\
\hline GGHSS Titter Khel Lakki. & 3 & 3 & 4 & 4 & 3 & \\
\hline GGHSS Mulazai Tank & 3 & $3.08(62 \%)$ & $3.25(65 \%)$ & $3.41(68 \%)$ & $3.16(63 \%)$ & $3.25(65 \%)$ \\
\hline
\end{tabular}

LP: Lesson Preparation, UAV: Use of AV Aids, DM: Discipline Management, DCR: Democracy in Class Room, TT: Teaching Techniques

The researcher targeted teacher performance over five different perspectives; lesson preparation, Use of AV aids, Discipline management, Democracy within the classroom, teaching techniques, and new pedagogies. It is quite interesting to note the researcher found the quite encouraging situation concerning the lesson in the GGHS Schools. Out of a total score of 5 points the average score achieved by the GGHSS Schools was (3.08\%), Use of AV aids within the classroom got a score of 3.25 out of $5(65 \%)$, Discipline management within the classroom by the SS got 3.41 out of 5 making it $(68 \%)$ It was quite depressing to note that democracy within the classroom got only 3.16 out of 5 making it a $63 \%$ score. Teaching techniques and new pedagogies got 3.25 out of 5 points making it a $65 \%$ score.

The researcher collected academic scores of the students appearing in HSSC Part II of the sampled out schools through gazettes of the respective BISEs of the area. A comparison was then made between the scores of the school in terms of availability of the instructional material and their annual HSSC Part-II result.

Table 3: Showing schools wise comparative analysis of academics results and availability of instructional environment

$\begin{array}{cc}\text { School Name } & \begin{array}{c}\text { Average of } 3 \\ \text { years } \\ \text { School results }\end{array}\end{array}$

\section{Average scores of SS in teacher performance checklist (25)}

\author{
Scores in \\ Instructional \\ Environment \\ Checklist (25)
}


https://doi.org/10.18510/hssr.2021.9383

\begin{tabular}{llll}
\hline GGHSS No 2, DIK & $82 \%$ & $17(68 \%)$ & $13(52 \%)$ \\
\hline GGHSS No 9, DIK & $93 \%$ & $19(76 \%)$ & $14(56 \%)$ \\
\hline $\begin{array}{l}\text { GGHSS Bilot } \\
\text { Shareef, DIK }\end{array}$ & $79 \%$ & $18(72 \%)$ & $12(48 \%)$ \\
\hline $\begin{array}{l}\text { GGHSS Jungle Khel } \\
\text { Kohat }\end{array}$ & $50 \%$ & $15(60 \%)$ & $13(52 \%)$ \\
\hline GGHSS Lachi, Kohat & $74 \%$ & $13(52 \%)$ & $10(40 \%)$ \\
\hline $\begin{array}{l}\text { GHSS Gumbat, } \\
\text { Kohat }\end{array}$ & $89 \%$ & $16(64 \%)$ & $11(44 \%)$ \\
\hline GGHSS Karak No1 & $94 \%$ & $16(64 \%)$ & $11(44 \%)$ \\
\hline $\begin{array}{l}\text { GGHSS Chokara } \\
\text { Karak }\end{array}$ & $95 \%$ & $17(68 \%)$ & $10(40 \%)$ \\
\hline GGHSS SK Bala & $84 \%$ & $15(60 \%)$ & $11(44 \%)$ \\
\hline GGHSS Kaki, Bannu & $99 \%$ & $14(56 \%)$ & $11(44 \%)$ \\
\hline $\begin{array}{l}\text { GGHSS Titter Khel } \\
\text { Lakki. }\end{array}$ & $94 \%$ & $17(68 \%)$ & $11(44 \%)$ \\
\hline $\begin{array}{l}\text { GGHSS Mulazai } \\
\text { Tank }\end{array}$ & $50 \%$ & $15(60 \%)$ & $10(40 \%)$ \\
\hline
\end{tabular}

The comparison between the average academic results of the students in HSSC Part II and the availability of instructional environment shows quite an interesting picture. The GGHS Schools like Karak No 1, Chowkara, Kaki, Titter Khel, and GGHS no 9, DIK show more than $90 \%$ academic pass percentage while lagging behind in the availability of instructional environment scores.

$\mathbf{H}_{01}$ : No significant correlation exists between instructional environment and performance of the SS in terms of exam results of students in HSSC Part II

Table 4: Showing correlation between the performance of SS in term of exam results and instructional environment in school

\begin{tabular}{|c|c|c|c|}
\hline Correlation & & $\begin{array}{l}\text { Average results of } \\
\text { students in HSSC } \\
\text { Part II }\end{array}$ & $\begin{array}{l}\text { availability } \\
\text { instructional } \\
\text { environment }\end{array}$ \\
\hline \multirow{3}{*}{$\begin{array}{l}\text { Average results of students in } \\
\text { HSSC Part II }\end{array}$} & Pearson Correlation & 1 & -.022 \\
\hline & Sig. (2-tailed) & & .000 \\
\hline & $\mathrm{N}$ & 12 & 12 \\
\hline \multirow{3}{*}{$\begin{array}{l}\text { Availability } \\
\text { environment }\end{array}$} & Pearson Correlation & -.022 & 1 \\
\hline & Sig. (2-tailed) & .000 & \\
\hline & $\mathrm{N}$ & 12 & 12 \\
\hline
\end{tabular}

After applying Pearson's test, the researcher found a significant but negative correlation at 0.05 significance level which is -.022 among two variables showing that the improvement in the instructional environment leads to a decrease in performance of the subject specialists in terms of results of students in HSSC Part II. Thus the hypothesis is accepted.

$\mathbf{H}_{\mathbf{0 2}}$ : No significant correlation exists between the performance of SS within the classroom and the availability of a conducive instructional environment in schools.

Table 5: Showing the correlation between the performance of SS in the classroom and a better instructional environment in school.

\begin{tabular}{llll}
\hline Correlation & & Scores & classroom performance of teachers \\
\hline \multirow{3}{*}{ Scores } & Pearson Correlation & 1 & -.011 \\
\cline { 2 - 4 } & Sig. (2-tailed) & & .000 \\
\cline { 2 - 4 } & $\mathrm{N}$ & 12 & 12 \\
\hline \multirow{3}{*}{ Classroom performance of teachers } & Pearson Correlation & -.011 & 1 \\
\cline { 2 - 4 } & Sig. (2-tailed) & .000 & \\
\cline { 2 - 4 } & $\mathrm{N}$ & 12 & 12 \\
\hline
\end{tabular}

In the above table, Pearson correlation test was applied to measure association among the two variables. The results of the test was -.011 at 0.05 significance level shows significant negative correlation exists among two variables leading to the fact that as the instructional environment get improved the classroom performance of teachers decreases.

\section{DISCUSSION}

Aiming to identify the situation of the instructional environment within the girls' higher secondary schools in KP, the study targets the perception of the stakeholders regarding the nature and availability of resources that combine to form 
an instructional environment within an institution. The researcher used a self-developed properly validated and reliable observational checklist for this purpose which included items related to school structure, availability of instructional materials within and outside the classroom, opportunities of professional development for teacher, learning-friendly environment within the school, stress on the overall development of the students within the classroom enhances teacher and student performance. On the other hand, this study also targets the performance of teachers and attempts to know whether the availability or lack thereof of a good instructional environment contribution to enhancing teachers' performance. The researcher has found quite a lot of research studies that take the educational achievement of the students as the criteria upon which the performance of teachers can be judged. However, Nazir (2012) \has advocated for evaluation of teacher performance upon more than one criterion. It is considered to be a complex procedure and limiting it to just one or few criteria may not provide actual and authentic results (Kigenyi, 2017).

Thus knowledge-based tests for teachers, student achievement records, observational checklists filled by a trained observer as well as performance in workshops and training programs should all be considered (Shishigu, 2015) Thus, the researcher collected the required data about teacher performance from two sources, and duly authenticated and reliable observational checklist which was filled by the researcher herself during personal visits to each school. It contained items related to lesson preparations, use of the latest teaching pedagogies, the democratic environment within the classroom, use of AV aids, and management of discipline within the classroom. The results of the study show quite interesting facts. The score of each cluster school relating to the instructional environment was found to be diverse from others. School structure; spacious classrooms, electricity, ventilation, lavatories, staffrooms, refreshment areas for staff and students were found by the researcher to be present in variation in each higher secondary school under consideration. Out of the twelve schools, only 2 schools GGHSS No.9, Dera Ismail Khan, and GGHSS Jungle Khel, Kohat scored high in the checklist whereas the rest of the 10 schools were found to have average scores with a low level of infrastructural facilities. Similarly, below-average availability of instructional material within the classrooms was found in the schools with the exception of just a few schools. It is interesting to note that all the higher secondary schools scored equally in the provision of professional development to the teachers because of the undergoing professional development programs sponsored by the Education Department, KP. Such factors may contribute to negative relationship between studied variables which needs to be improved for developing positive relationship as it is essential for betterment of Institutes.

The researcher found a lack of learner-friendly environment in most of the schools except for just one, GGHSS Bilot Sharif, D.I.Khan. Generally speaking, it can be said that the schools scored below average on the checklist about the availability of a better instructional environment. As mentioned earlier, the researcher used two different techniques to judge the performance of the teachers. On one hand, an average was calculated of the 3 years HSSC Part II results of all the selected schools while on the other hand looking at the scores of teachers from each selected higher secondary school, on the observational checklist was calculated. It was noted that most of the subject specialists scored high on the checklist. Whether it was lesson plan preparation, use of AV aids, discipline management within the classroom, creating a democratic environment of use of the latest teaching pedagogies, most of the subject specialists, with the exception of a few, scored above average points. A bird's eye view upon Table 3 shows a clear picture about the fact that even in those schools that have scored low on the availability of instructional environment, the performance of teachers is above average, whether it is seen in terms of last three years results of HSSC Part II or in terms of their scores in the checklist.

\section{CONCLUSION}

The results of this research study provide food for thought for the educationists as well as the policymakers. Below average availability of instructional material within the classrooms was found in the schools with the exception of just a few schools. Lack of proper work environment and learning facilities have failed to waver the commitment of the female's subject specialists of the southern districts of KP who have shown excellent performance while fighting with odds within their schools. A subject specialist from the majority of the district scored high points when looked at the perspective of the observational checklist irrespective of the fact that a proper work environment was found to be lacking in most of the higher secondary schools. The performance of the subject specialists was found to be above average when looked at from the perspective of BISE results for the last three years. The present study endorses the efforts made by the education department to provide professional development opportunities to the teachers. There found a significant negative correlation between instructional environment and performance of the SS in terms of exam results of students in HSSC Part II and there found significant negative correlation between the performance of SS within the classroom and the availability of conducive instructional environment in schools.

\section{LIMITATIONS}

Like all other studies, this study also has limitations. First, this study was conducted only in the southern district of KP at only secondary level and that's maybe the reason such were found. The instrument used in this study was also not considered to be perfect as a questionnaire and more importantly, interviews are far better to explore hidden facts. The instrument used was due to the convenience of the researcher in terms of time availability and financial resources.

\section{RECOMMENDATIONS FOR FUTURE STUDY RESEARCH}

Future researcher can research on the given variables in other zones of KP and other provinces of Pakistan. Future researchers need to research with the methodology that can bring a depth of the phenomenon along with comprehensive 
reasons that are qualitative or either mixed-method study to cross-check the results. The sample size can be increased and other groups that have deep concerns with teacher performance and instructional environment must be included like principals, students, and administrators.

\section{ACKNOWLEDGEMENT}

There is no financial support by any organization. This study was done by Ph.D. Scholar: Samina Naz and this article is required for receiving a Doctoral degree from Gomal University, D.I.Khan. She is the corresponding author of this article. Her Efforts are truly acknowledged.

\section{AUTHORS CONTRIBUTION}

Samina Naz started the research study as Ph.D. requirement. She selected the topic, wrote an introduction and literature review. She also collected the data from the respondents from the selected clusters. She analysed the data and presented findings. Dr. Malik Amir Atta was the supervisor of Samina Naz and he supervised her throughout the study. Abdul Ahad Roshan Saeed worked on plagiarism. Shagufta Naz worked on the organization and editing of the paper. She overviews the final draft for further improvement and correction of the reviews by the journal's editorial members

\section{REFERENCES}

1. Ahmed, U., Umrani, W. A., Qureshi, M. A., \& Samad, A. (2018). Examining the links between teachers support, academic efficacy, academic resilience, and student engagement in Bahrain. International Journal of Advanced and Applied Sciences, 5(9), 39-46. https://doi.org/10.21833/ijaas.2018.09.008

2. Antičević, V., Kardum, G., Klarin, M., Sindik, J., \& Barač, I. (2018). Academic Achievement and Study Satisfaction: The Contribution of High School Success and Personality. Društvena istraživanja: časopis za opća društvena pitanja, 27(2), 243-260. https://doi.org/10.5559/di.27.2.03

3. Arif, H. M. (2003). Human development and learning. Majeed Book Depot, Lahore, Pakistan, 163.

4. Baroody, A. E., \& Diamond, K. E. (2016). Associations among preschool children's classroom literacy environment, interest and engagement in literacy activities, and early reading skills. Journal of Early Childhood Research, 14(2), 146-162. https://doi.org/10.1177/1476718X14529280

5. Basri, W. S., Alandejani, J. A., \& Almadani, F. M. (2018). ICT adoption impact on students' academic performance: Evidence from Saudi universities. Education Research International, 2018. https://doi.org/10.1 $155 / 2018 / 1240197$

6. Buckley, J., Schneider, M., \& Shang, Y. (2005). Fix it and they might stay: School facility quality and teacher retention in Washington, D.C. Teachers College Record, 107, 1107-1123. https://doi.org/10.1111/j.14679620.2005.00506.x

7. Cascio. (2006). Managing Human Resource: Productivity, Quality of Work-life, Profits. Singapore: McGrawHill International Editors.

8. Dornyei, Z. (2001) Teaching and Researching Motivation, England: Pearson Education Limited. Education for All Global Monitoring Report, (2005) UNESCO, Paris.

9. Han, J., Schlieber, M., \& Gregory, B. (2017). Associations of home and classroom environments with Head Start children's code-related and oral language skills. Journal of Education for Students Placed at Risk (JESPAR), 22(4), 200-219. https://doi.org/10.1080/10824669.2017.1347044

10. Harrison, F., \& Jones, A. P. (2012). A framework for understanding school-based physical environmental influences on childhood obesity. Health \& place, 18(3), 639-648. https://doi.org/10.1016/j.he althplace.2011.12.009

11. Hartinah, S., Suharso, P., Umam, R., Syazali, M., Lestari, B., Roslina, R., \& Jermsittiparsert, K. (2020). Retracted: Teacher's performance management: The role of principal's leadership, work environment and motivation in Tegal City, Indonesia. Management Science Letters, 10(1), 235-246. https://doi.org/10.526 7/j.msl.2019.7.038

12. Haseeb, M. A., \& Sattar, S. A. (2018). Exploring the causes of job stress and coping strategies among the faculty of public universities. Journal of Education and Human Development, 7(4), 27-33. https://doi.org/ 10.15640/jehd.v7n4a4

13. Ikhwandra, I. (2016). Pengaruh kepemimpinan kepala madrasah terhadap kinerja guru pada mas sekabupaten tanah datar. al-fikrah: Jurnal Manajemen Pendidikan, 1(2), 161-170. https://doi.org/10.31958/jaf.v1i2.361

14. Jirangkul, W. (2017). Implementing the Casual Effect of Leadership to High-Performance Organizations: An Empirical Study of Public Organizations. International Journal of Crime, Law and Social Issues, 4(2). https://doi.org/10.2139/ssrn.3261839

15. Kigenyi, Erisa \& Kakuru, Doris \& Ziwa, Gertrude. (2017). School environment and performance of public primary school teachers in Uganda. International Journal of Technology and Management, 1-14.

16. Korir, I., \& Kipkebut, D. (2016). The effect of reward management on employees commitment in the universities in Nakuru County-Kenya. Journal of Human Resource Management, 4(4), 37-48. https://doi.org/10.11648/j.jhrm.20160404.12 
17. Lious, N. A. T., Oliveira, H. M. S., \& Pimentel, L. M. (2021). Good Working Environment and Work Performance Across Higher Institutions in Buea. Asian Journal of Economics, Business and Accounting, 64-89. https://doi.org/10.9734/ajeba/2021/v21i130340

18. Lixia, C. (2017). The relationship between teachers' leadership styles and teaching quality in lower secondary schools in Liang Zhou District of Wuwei, Gansu, China. Asian Political Science Review, 1(1), 71-78. https://doi.org/10.12778/235108617X15452339029545

19. Lynch, J.M. 2012. Responsibilities of today's principal: Implications for principal preparation programs and principal certification policies. Rural Special Education Quarterly, 31(2), 40. https://doi.org/10.1177/8 75687051203100205

20. Madrid, D., Ahmed, U., \& Kumar, R. (2019). Examining the Impact of Classroom Environment on Entrepreneurship Education: Case of a Private University in Bahrain. Journal of Entrepreneurship Education, 22(1), 1-8.

21. Marry, A. (2010). Motivation and the performance of primary school teachers in Uganda: A case of KimaanyaKyabankuza division, Madaka District. Unpublished (Master of Arts) dissertation Makerere University, Kampala, Uganda.

22. Medley, D. M. (1977). Teacher Competence and Teacher Effectiveness. A Review of Process-Product Research.

23. Mureithi, Z. N., \& Mwangi, B. N. (2019). Influence of selected factors on academic performance of public preschool learners in nyeri central sub-county, nyeri county, kenya. Journal of Education and Practices, 2(1), 16-16.

24. Nazir N \& Mattoo N H, (2012) A Study on Impact of School Environment on Academic Achievement among Adolescents. International Journal of Social Science Tomorrow, 1(5).

25. Ofoegbu, F.I., (2004). Teacher Motivation: A Factor for Classroom Effectiveness and School Improvement in Nigeria. www.CollegeStudentJournalFindArticles.com, Accessed on 12 July, 2010.

26. Park, C. K., Lim, D. H., \& Ju, B. (2016). Transformational leadership and teacher engagement in an international context. Handbook of research on global issues in next-generation teacher education, 22-42. https://doi.org/10.4018/978-1-4666-9948-9.ch002

27. Ruth, B. (2017). Kemampuan komunikasi antar pribadi dan motivasi mengajar terhadap kinerja guru sekolah menengah atas Jakarta Timur. Teraputik, 1(1), 53-59. https://doi.org/10.26539/1111

28. Shishigu, Aweke. (2015). Factors Affecting Teachers Motivation and Professionalism: The Case of Public Primary Schools in Addis Ababa, Ethiopia. The International Journal of Humanities \& Social Studies.

29. Thanomton, C., Niyamabha, A., Wichitputchraporn, W., \& Koedsuwan, S. (2018). A Causal Model of Transformational Leadership and School Environments through Basic Psychological Needs Affecting Teachers' Engagement in Professional Learning in Schools under the Bangkok Metropolitan Administration. PSAKU International Journal of Interdisciplinary Research, 7(2).

30. Ye, Y. (2017). A Study on Chinese Teachers' Competence, Challenges and Ability to Handle the Challenges at International Schools in Bangkok, Thailand. PSAKU International Journal of Interdisciplinary Research (PSAKUIJIR), 6(1). https://doi.org/10.12778/235108618X15452373185804 